\title{
Effects of slow liquid transit on colonic fermentation in vitro
}

\author{
Hakan ÖZTÜRK ${ }^{1}$, Vedat SAĞMANLIGÍL ${ }^{1}$, Gerhard BREVES ${ }^{2}$ \\ ${ }^{1}$ University of Ankara, Department of Physiology, Faculty of Veterinary Medicine, Ankara, Turkey; ${ }^{2}$ Department of Physiology, \\ School of Veterinary Medicine, Hannover, Germany.
}

\begin{abstract}
Summary: The colonic microflora and their fermentation end-products play important roles in host health. The objective of this study was to determine the biochemical responses of colon microflora to slow colonic transit. For this purpose, the study was carried out with the colon simulation technique (Cositec). Inocula and fermentable substrates were obtained from colon contents of slaughtered pigs. To simulate slow colonic transit, the liquid turnover rate in the Cositec system was decreased by ca. \%50. Slow liquid turnover resulted in a significant decrease in $\mathrm{pH}$, total short-chain fatty acids (SCFAs), acetate and propionate productions. However, the production of butyrate was not significantly affected by the treatment. The redox potential was affected by slow liquid turnover and became more positive. Organic matter digestibility increased in response to slow liquid turnover. These results indicated that slow liquid turnover altered biochemical milieu within the colon and this may play a key role in the pathogenesis of colorectal diseases.
\end{abstract}

Key words: Colon, Cositec, fermentation, slow liquid turnover.

\section{Yavaş sıvı geçişinin kolonik fermantasyon üzerine in vitro etkileri}

Özet: Kolon mikroflorası ve fermentasyon son ürünleri konakçı sağlığı üzerinde önemli roller oynamaktadır. Bu araştırmada, kolon mikroflorasının yavaş kolonik geçişe gösterdiği yanıtı belirlemek amaçlandı. Bu amaçla, araştırmada Cositec tekniği (Colon Simulation Technique) kullanıldı. İnkübasyon için gerekli inokulum ve substratlar kesimhanede, kesilmiş domuzların kolon içeriklerinden temin edildi. Yavaş kolonik geçişi taklit etmek için Cositec sistemde sıvı döngüsü yaklaşık \% 50 oranında azaltıldı. Azaltılmış sıvı döngüsü pH değerinde, toplam kısa zincirli yağ asitleri (SCFAs), asetat ve propiyonat üretimlerinde belirgin bir azalmaya neden olurken, bütirat üretimini etkilemedi. Redoks potansiyeli yavaş sıvı döngüsünden etkilenerek daha pozitif değerlere ulaştı. Yavaş sıvı döngüsü organik madde sindirilebilirliğinde ise artışa neden oldu. Bu araştırmanın sonuçları, yavaş sıvı döngüsünün kolondaki biyokimyasal ortamda önemli değişiklikler yaptığını göstermektedir. Bu değişikliklerin kolorektal hastalıkların patogenezinde kilit rol oynayabileceği düşünülmektedir.

Anahtar sözcükler: Cositec, fermantasyon, kolon, yavaş sıvı döngüsü.

\section{Introduction}

The importance of colon microflora within the gastrointestinal tract has become evident by numerous studies showing the role of intestinal microorganisms in the synthesis of fermentation products that provide energy to the colon epithelium (7), the stimulation of the gut immune system (15), the synthesis of vitamins $\mathrm{K}$ and $\mathrm{B}$ (4) and the colonization resistance against exogenous pathogens (10). Clinically significant delay in gastric emptying and small intestinal and colonic transit occurs in a variety of diseases and conditions such as diabetes mellitus, anorexia nervosa, scleroderma, myotonic dystrophy, hypoparathyroidism, postvagotomy, postoperative ileus, and spinal cord injury. Delayed transit may also occur due to functional disorders of no known etiology, such as nonulcer dyspepsia, idiopathic intestinal pseudoobstruction, irritable bowel syndrome, and idiopathic constipation (16). Experimental data on the effects of slow transit on colon microflora and colonic fermentation are scarce. The specific aim of the present study was to determine using in vitro Cositec system the biochemical responses of colon microflora to slow colonic transit.

\section{Materials and Methods}

Incubation technique: The experiment was carried out with the Cositec system, an in vitro method for the semi-continuous incubation of colon contents, previously described by Breves et al. (3). This method was originally developed as rumen simulation technique (Rusitec) by Czerkawski and Breckenridge (9). The applicability of the Cositec system for long-term in vitro studies on parameters of microbial metabolism has been proven by Stück et al. (18). As a modification to the originally described method, colonic fluid and particle phase were obtained from freshly slaughtered pigs. The animals had been adapted to a finishing diet consisting of $46.2 \%$ barley, $35 \%$ wheat, $15 \%$ defatted soy bean meal and 
$1.5 \%$ soy oil. Vitamins and minerals were supplemented according to the recommendations of the German Society of Nutritional Physiology (1). The diet contained 16.4\% CP, 3.4\% EE, $4.1 \% \mathrm{CF}$ and $6.1 \% \mathrm{CA}$ and $88.4 \% \mathrm{DM}$.

At the beginning of the experiment $125 \mathrm{ml}$ gauzefiltrated caecal fluid were introduced into each fermentor which contained a perforated internal vessel with two nylon bags (40 $\mu \mathrm{m}$ mesh size). Approximately $2.8 \mathrm{~g}$ freeze-dried caecal particles representing the physiological predigested substrate were added into each nylon bag. For the experiment, five fermentors were incubated simultaneously at $39^{\circ} \mathrm{C}$ under anaerobic conditions. The nylon bags were exchanged alternately at $24 \mathrm{~h}$ intervals in order to achieve a particle retention time of $48 \mathrm{~h}$. The fermentors were continuously perfused with an isotonic buffer solution, which contained (in mmol/l) $\mathrm{NaCl} 115$, $\mathrm{KCl} 10, \mathrm{CaCl}_{2} 2.5, \mathrm{MgCl}_{2} 2.5, \mathrm{NaOH} 0.2, \mathrm{NaH}_{2} \mathrm{PO}_{4} 2$, $\mathrm{Na}_{2} \mathrm{SO}_{4} 1, \mathrm{NaHCO}_{3} 25$ and $\mathrm{NH}_{4} \mathrm{Cl} 5$ (302 mosm/l, pH 7.35). The nominal volume in each fermentor was $125 \mathrm{ml}$ and the dilution rate was set at $625 \mathrm{ml} / \mathrm{d}$. This rate was comparable with the flow of ileal fluid into the pig colon.

Experimental procedures: Five fermentors of the Cositec system were run for a total period of 14 days. The total period was divided into three phases as equilibration, control and experimental phases. Before any experimental procedure, the system was allowed to equilibrate for a five-day period (to achieve steady state conditions). The following 4 days were used to determine basic parameters of microbial metabolism under control conditions at a buffer infusion rate of $625 \mathrm{ml} /$ day. The last 5 days served as the experimental phase. In this last phase the infusion rate of the buffer solution was decreased from 625 to $315 \mathrm{ml} /$ day.

Analytical procedures: The $\mathrm{pH}$ values and redox potentials were measured daily in each fermentor at the time of feeding using a $\mathrm{pH}$ electrode (Typ 408 and $\mathrm{Pt}$ 4805-S7/120, Mettler Toledo, Steinbach, Germany) connected to a Knick pH meter (digital pH meter 646, Knick, Berlin, Germany). Liquid effluent was collected daily and samples were taken for analyses of SCFAs. The overflow flasks were placed into ice to stop microbial activity and preserve fermentation products. Concentrations of SCFAs were determined by gas chromatography (11). An aliquot of effluent was centrifuged at $40.000 \times \mathrm{g}$ for $20 \mathrm{~min}$ at $4{ }^{\circ} \mathrm{C}$. The resulting supernatant was acidified with $0.1 \mathrm{ml}$ of $98 \%$ formic acid and then centrifuged at $4000 \times \mathrm{g}$ for $10 \mathrm{~min}$ at $4^{\circ} \mathrm{C}$. The supernatant was analyzed for SCFAs by gas chromatography (model 5890 II, Hewlett Packard, Böblingen, Germany) equipped with a $1.8 \mathrm{~m} \times 2 \mathrm{~mm}$ glass column packed with Chromosorb WAW (mesh $80 / 100$ ) with $20 \%$ neopentyl glycol succinate and $2 \%$ ortho phosphoric acid. Helium was used as a carrier gas with a flow rate of $25 \mathrm{ml} / \mathrm{min}$. Injection port, detector, and oven temperatures were 220,250 , and $130{ }^{\circ} \mathrm{C}$, respectively. Daily production rates of SCFAs were estimated by multiplying the respective concentration by the volume of effluent collected. The non-fermented residues within the nylon bags were weighed and burned to ashes to determine the digestibility of the organic matter (12).

Statistical analyses: Results were expressed as means values with their standard deviation (SD); $n$ designates the number of fermentors run in parallel. Statistical analysis was performed by SPSS 13.0 software (SPSS Inc., Chicago, IL, USA). Differences between parameters measured before and after treatment were first tested with nonparametric Friedman test (because of the small sample sizes: $n=5$ ). In case of a significant difference, Wilcoxon signed rank test was applied for the particular comparison. $\mathrm{P}$ values $<0.05$ were considered significant.

\section{Results}

Mean $\mathrm{pH}$ values in colonic fluid during the experiment are shown in Figure 1. Slow liquid turnover caused a rapid decrease in the mean colonic $\mathrm{pH}$ from $6.70 \pm 0.04$ to $6.42 \pm 0.08(\mathrm{p}<0.05)$.

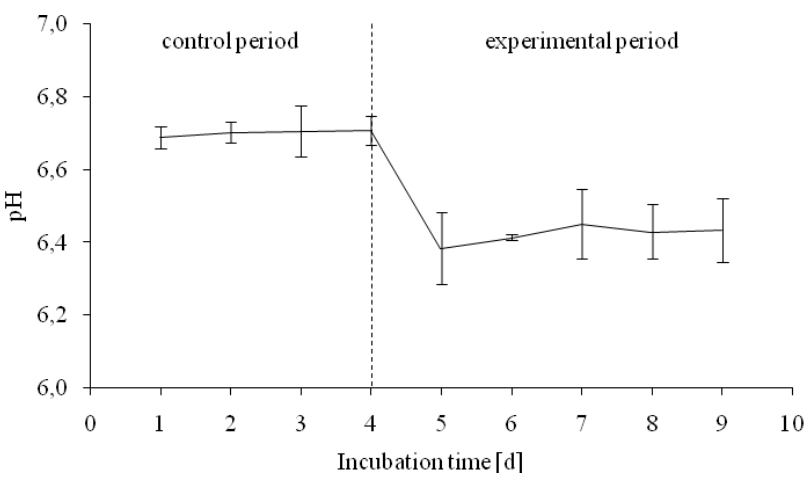

Figure 1: Effect of slow liquid turnover on colonic $\mathrm{pH}(\mathrm{n}=5)$

Şekil 1: Yavaş sıvı döngüsünün kolonik pH üzerine etkisi $(\mathrm{n}=5)$

The redox potentials as a measure of anaerobic conditions were significantly $(\mathrm{p}<0.05)$ affected by decreased turnover rate and became more positive and increased from $-246 \pm 9 \mathrm{mV}$ to $-236 \pm 8 \mathrm{mV}$ (Figure 2).

Total SCFAs production rates decreased by $\% 15$ from $6.05 \pm 0.34$ to $5.14 \pm 0.24 \mathrm{mmol} /$ day obtained in the control and experimental periods, respectively (Figure 3 ). In general, these reductions were mediated by respective changes in the production rates of acetate and propionate (Figure 3).

However, the production rate of butyrate was not significantly affected by decreasing liquid turnover $(0.70$ $\pm 0.06 \mathrm{mmol} /$ day $)$ compared to the data $(0.68 \pm 0.04$ $\mathrm{mmol} / \mathrm{day}$ ) obtained in the control period (Figure 3 ). 


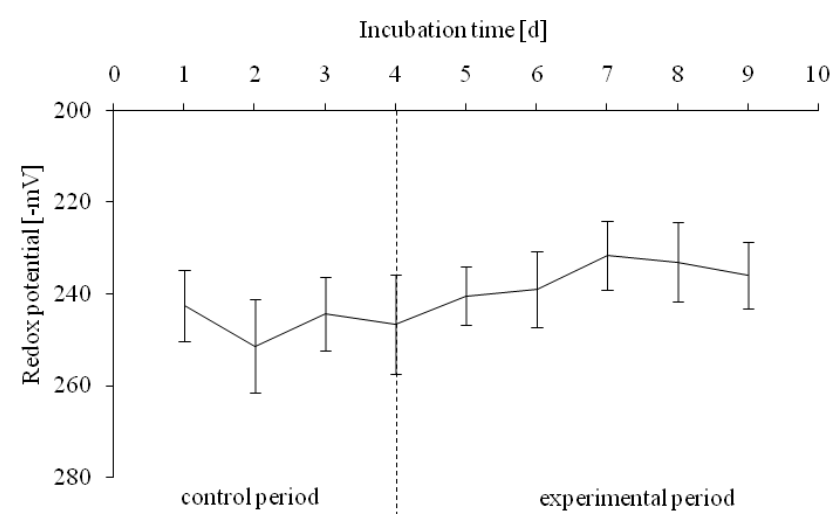

Figure 2: Effect of slow liquid turnover on redox potential $(\mathrm{n}=5)$

Şekil 2: Yavaş sıvı döngüsünün redoks potansiyeli üzerine etkisi $(\mathrm{n}=5)$

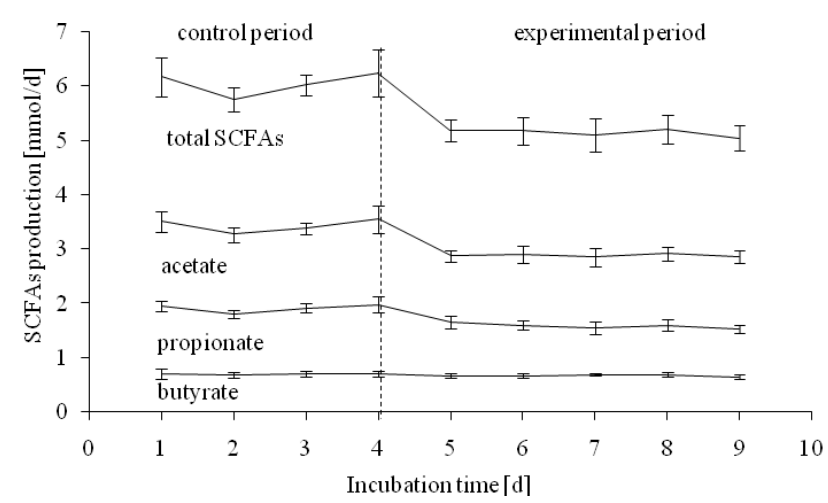

Figure 3: Effect of slow liquid turnover on SCFAs production $(\mathrm{n}=5)$

Şekil 3: Yavaş sıvı döngüsünün SCFA'ların üretimi üzerine etkisi $(n=5)$

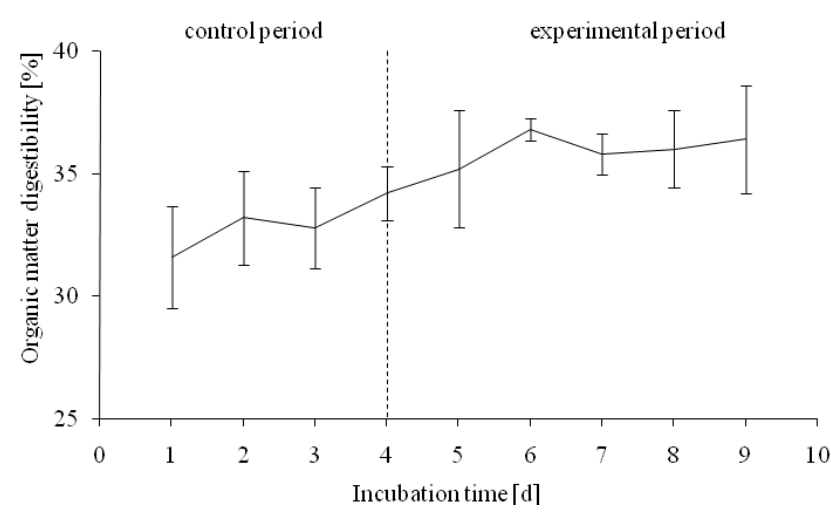

Figure 4: Effect of slow liquid turnover on digestibility of organic matter $(\mathrm{n}=5)$

Şekil 4: Yavaş sıvı döngüsünün organic madde sindirilebilirliği üzerine etkisi $(\mathrm{n}=5)$

The result of organic matter digestibility as affected by slow turnover rate was presented in Figure 4. Compared with the control period, no significant difference was observed in the organic matter digestibility on the first day after the treatment $(p=0.07)$. Towards the end of the experimental period the organic matter digestibility was increased from a control level of $33 \%$ to $36 \%(p<0.05)$.

\section{Discussion and Conclusion}

The colon is relatively inaccessible and a difficult area to investigate colonic microbial metabolism in vivo. Therefore, numerous investigations on colonic microbial metabolism have been undertaken with feces. However, it has to be taken into account that the composition of the microbial flora and the relationship between living and inactivated microorganisms differ substantially between feces and contents from upper colon (2). Besides, fermentation end products (i.e. $95 \%$ of the SCFAs) generated in the colon are absorbed from the colon during transit of effluent through the gut (6). As a consequence, determinations of fecal SCFAs cannot be directly related to the events taking place in the colon itself (8). One approach to solving this problem is to use in vitro fermentation methods. Therefore, a great part of the experimental data available to date has been derived from in vitro investigations with fecal batch cultures. As an alternative, an in vitro anaerobic semi-continuous culture system has been established with bacterial populations similar to the colonic flora (18). The Cositec system has some advantages compared with fecal incubation systems. Firstly, the microbial population and material are obtained from the physiological relevant regions within the colon. Secondly, the accumulation of end-products can not occur due to its semi-continuous character. The fermentable substrate offered, i.e. freezedried cecal/colonic contents, has previously passed the digestive processes in the small intestine and is therefore identical to the material that the microbes have to deal with in vivo. Preceding studies with the Cositec system have shown that the results obtained are close accordance with parameters measured in vivo, are highly reproducible and can characterize factors of physiological variance in the microbial metabolism in colon $(2,3,18)$.

Despite an increased interest in gastrointestinal physiology and intestinal microflora, as well as interaction between them, only very limited direct studies are available on the effects of slow colonic transit on colonic fermentation. In this study, decreasing the buffer infusion by approximately $50 \%$ resulted in a decrease in $\mathrm{pH}$ and SCFAs production except butyrate and in an increase in redox potential and digestibility of organic matter. Walker et al. (20) reported that a major factor tending to decrease colonic $\mathrm{pH}$ is the production of SCFAs by microbial fermentation of dietary carbohydrate that is digestible by colon microorganisms but not by host enzymes. In this study, the decrease in the liquid turnover (by ca. 50\%) was much more efficient than the reduction in the production rate of SCFAs (by ca. 15\%) and this could be involved in an accumulation of SCFAs in the fermentors and in a drop of $\mathrm{pH}$. Whereas the daily 
productions of SCFAs were decreased, the digestibility of organic matter was increased after the treatment. Low SCFAs production could be associated with a less efficient fermentation and energy generation at slow liquid turnover. In this study, slow liquid turnover could allow more time for bacterial proliferation and lead to limited soluble energy sources in the fermentors of the Cositec system. One consequence of this is that cell yields fall at decreasing dilution rate. Time is an important factor in the conversion of carbohydrate to bacterial cell mass because with longer residence times in the gut, bacteria divert a proportionally greater amount of energy into the maintenance of cellular functions rather than growth. These non-growth functions were designated as maintenance energy (14). Despite the low SCFAs production, the increase in the organic matter digestibility also supported the hypothesis that bacteria utilize organic substrates for their surviving rather than growing. Furthermore, redox potential is an indicator for both anaerobic conditions and for fermentation intensity (13).

There is mounting evidence that SCFAs play a key role in colonic health and may play a key role in the prevention and management of certain diseases due to their role as nutrients for the colonic epithelium, as modulators of colonic and intracellular $\mathrm{pH}$, cell volume, and other functions associated with ion transport, and as regulators of proliferation, differentiation, and gene expression $(5,21)$. Diminished concentrations of SCFAs have been linked to occurrence of diverticular disease, inflammatory bowel disease (Crohn's disease and ulcerative colitis), colorectal adenomatous polyps, colorectal cancer, and constipation $(17,19)$.

The results of the present study have shown that slow liquid turnover alters the biochemical milieu within the colon contents and these changes may have an important role in the pathogenesis of colorectal diseases and may cause some colonic disorders.

\section{References}

1. Ausschuss für Bedarfsnormen der Gesellschaft für Ernährungsphysiologie (1987): Energie- und Nährstoffbedarf landwirtschaftlicher Nutztiere, Nr. 4 Schweine, DLGVerlag, Frankfurt a. M., Germany.

2. Bender A, Breves G, Stein J, Leonhard-Marek S, Schröder B, Winckler C (2001): Colonic fermentation as affected by antibiotics and acidic pH: application of an in vitro model. Z Gastroenterol, 39, 911-918.

3. Breves G, Dreyer J, Oslage HJ (1991): In vitro-studies on microbial hindgut metabolism in pigs. Anim Physiol Anim Nutr, 22, 89-92.

4. Conly JM, Stein K (1992): The production of menaquinones (vitamin-K2) by intestinal bacteria and their role in maintaining coagulation homeostasis. Prog Food Nutr Sci, 16, 307-343.

5. Cook SI, Sellin JH (1998): Review article: short chain fatty acids in health and disease. Aliment Pharmacol Ther, 12, 499-507.
6. Cummings JH (1981): Short-chain fatty acids in the human colon. Gut, 22, 763-779.

7. Cummings JH, Englyst HN (1987): Fermentation in the human large-intestine and the available substrates. Am J Clin Nutr, 45, 1243-1255.

8. Cummings JH, Macfarlane GT (1991): A review: The control and consequences of bacterial fermentation in the human colon. J Appl Bacteriol, 70, 443-459.

9. Czerkawski JW, Breckenridge G (1977): Design and development of a long-term rumen simulation technique (Rusitec). Br J Nutr, 38, 371-384.

10. Hopkins MJ, Macfarlane GT (2003): Nondigestible oligosaccharides enhance bacterial colonization resistance against Clostridium difficile in vitro. Appl Environ Microbiol, 69, 1920-1927.

11. Oeztuerk H, Schroeder B, Beyerbach M, Breves G (2005): Influence of living and autoclaved yeasts of Saccharomyces boulardii on in vitro ruminal microbial metabolism. J Dairy Sci, 88, 2594-2600.

12. Orskov ER, Hovell FDDeB, Mould FL (1980): The use of the nylon bag technique for the evaluation of feedstuffs. Trop Anim Prod, 5, 195-213.

13. Öztürk H (2003): In-vitro-Studien zum Einfluss von Topinamburmehl und Saccharomyces boulardii auf den mikrobiellen Vormagenstoffwechsel. Dissertation, Tierärztliche Hochschule, Hannover, Germany, 91.

14. Russell JB (1986): Heat production by ruminal bacteria in continuous culture and its relationship to maintenance energy. J Bacteriol, 168, 694-701.

15. Salminen S, Bouley C, Boutron-Ruault MC, Cummings JH, Franck A, Gibson GR, Isolauri E, Moreau MC, Roberfroid M, Rowland I (1998): Functional food science and gastrointestinal physiology and function. $\mathrm{Br} \mathrm{J}$ Nutr, 80, 147-171.

16. Sarna SK, Gonzalez A, Ryan RP (2000): Enteric locus of action of prokinetics: ABT-229, motilin, and erythromycin. Am J Physiol, 278, G744-G752.

17. Segal I, Hassan H, Walker ARP, Becker P, Braganza J (1995): Fecal short chain fatty acids in South African urban Africans and whites. Dis Col Rectum, 38, 732-734.

18. Stuck K, Faul K, Hylla S, Stein J, Breves G (1995): The application of a semi-continuous colon simulation technique (COSITEC) for studying the effects of clindamycin on microbial hindgut metabolism. Z Gastroenterol, 33, 241-246.

19. Walker ARP, Segal I (1997): Effects of transition on bowel diseases in Sub-Saharan Africans. Eur J Gastroenterol Hepatol, 9, 207-210.

20. Walker AW, Duncan SH, MacWilliam Leitch EC, Child MW, Flint HJ (2005): $p H$ and peptide supply can radically alter bacterial populations and short chain fatty acid ratios within human colonic microbial communities. Appl Environ Microbiol, 71, 3692-3700.

21. Wong JM, de Souza R, Kendall CW, Emam A, Jenkins DJ (2006): Colonic health: fermentation and short chain fatty acids. J Clin Gastroenterol, 40, 235-243.

Geliş tarihi: 10.02.2009 / Kabul tarihi: 02.06.2009
Address for correspondence:
Dr. Hakan Öztürk
Ankara University, Faculty of Veterinary Medicine,
Department of Physiology
06110 Diskapi-Ankara, Turkey
e-mail:Hakan.Ozturk@veterinary.ankara.edu.tr 